Int. J. Dev. Biol. 61: 495-503 (2017)

doi: $10.1387 / \mathrm{ijdb} .170051 \mathrm{gc}$

\title{
Contribution of cranial neural crest cells to mouse skull development
}

\author{
TAOFEN WU ${ }^{1,2}$, GUIQIAN CHEN ${ }^{*, 1,3}$, FEI TIAN*,4 and HONG-XIANG LIU ${ }^{3}$ \\ ${ }^{1}$ School of Medicine, Jiaxing University, Jiaxing, China, ${ }^{2}$ College of Animal Science, Zhejiang University, Hangzhou, \\ China, ${ }^{3}$ Regenerative Bioscience Center, University of Georgia, Athens, USA and ${ }^{4}$ Department of Orthopedics, \\ Hangzhou First People's Hospital, Nanjing Medical University affiliated Hangzhou Hospital, Hangzhou, China
}

\begin{abstract}
The mammalian skull vault is a highly regulated structure that evolutionally protects brain growth during vertebrate development. It consists of several membrane bones with different tissue origins (e.g. neural crest-derived frontal bone and mesoderm-derived parietal bone). Although membrane bones are formed through intramembranous ossification, the neural crest-derived frontal bone has superior capabilities for osteoblast activities and bone regeneration via TGF, BMP, Wnt, and FGF signaling pathways. Neural crest (NC) cells are multipotent, and once induced, will follow specific paths to migrate to different locations of the body where they give rise to a diverse array of cell types and tissues. Recent studies using genetic mouse models have greatly advanced our knowledge of NC cell induction, proliferation, migration and differentiation. Perturbations or disruptions of neural crest patterning lead to severe developmental defects or diseases. This review summarizes recent discoveries including novel functions of genes or signaling molecules that are capable of governing developmental processes of neural crest patterning, which may function as a gene regulatory network in controlling skull development. The proposed regulatory network will be important to understand how the signaling pathways and genes converge to regulate osteoblast activities and bone formation, which will be beneficial for the potential identification of molecular targets to prevent or alleviate human diseases or disorders involving defective neural crest development.
\end{abstract}

KEY WORDS: neural crest, frontal bone, parietal bone, skull vault, mesoderm

\section{Introduction}

The mammalian skull vault is a highly regulated structure and exquisitely patterned during development. Several membrane bones occupy the skull vault, namely a pair of frontal and parietal bones and an unpaired inter-parietal bone. These bone elements have different tissue origins. Frontal bones derive from the cranial neural crest (CNC), and parietal bones stem from paraxial mesoderm-derived tissue (Jiang et al., 2002) (Fig 1). The inter-parietal bone itself is of dual tissue origins, which is the evolutionary consequence of the fusion between the crest-derived "postparietals" and the mesoderm-derived "tabulars" (Koyabu et al., 2012). The skull vault protects the brain and accommodates its growth. Although the tissue origins of the skull vault in mouse were identified late compared to that in birds through chick-quail chimaeras, this valuable model has brought up enough attentions to understand the genetic and molecular mechanism determining the regional differences within the mouse skull vault.

\section{Osteogenic potential of neural crest-derived osteoblast vs. mesoderm-derived osteoblasts}

The frontal bone exhibits distinct differences in osteogenic potential and regenerative capability depending on their origin (neural-crest vs. mesoderm-derived): 1) Osteoblasts from the neural crest-derived frontal bone are less differentiated, grow

Abbreviations used in this paper: BMP, bone morphogenetic protein; $\mathrm{CNC}$, cranial neural crest cell; EMT, epithelial-mesenchyme transition; Fb, frontal bone; FGF, fibroblast growth factor; $\mathrm{Pb}$, parietal bone.

\footnotetext{
*Address correspondence to: Guiqian Chen. School of Medicine, Jiaxing University, Jiaxing, 314001, China; Regenerative Bioscience Center, University of Georgia, Athens, 30602, USA.Tel: +1-706-254-0533. E-mail: gqchen@uga.edu (iD http://orcid.org/0000-0002-1809-6165

or Fei Tian. Department of Orthopedics, Hangzhou First People's Hospital, Nanjing Medical University Affiliated Hangzhou Hospital, Hangzhou, 310006, China. E-mail: tianfei1117@sina.com (iD http://orcid.org/0000-0002-0939-8217
} 
faster, and have a more rapid bone nodules formation compared to parietal bone-derived osteoblasts (Xu et al., 2007). 2) A higher level of activation of the FGF signaling pathway is found in the frontal bone (Li et al., 2010, Quarto et al., 2009), which profoundly impacts calvarial regeneration (Behr et al., 2010). 3) Active canonical Wnt signaling also contributes to intrinsic osteogenic potential and tissue regeneration in the neural crest-derived frontal bone (Quarto et al., 2010). Enhanced activation of Wnt signaling in the parietial bone can mimic a neural crest origin bone, like the frontal bone (Li et al., 2015). 4) Neural crest-derived osteoblasts have low apoptosis when stimulated by TGF-beta signaling (Senarath-Yapa et al., 2013). 5) In humans, gene expression profiling within these two bone elements (Homayounfar et al., 2015) indicates a broad spectrum of differentially expressed genes, but how and when they will initiate to orchestrate the features of skull vault with different origins remains elusive (Fig. 1).

\section{Origin of neural crest cells and a genetic mouse model to label neural crest cells}

Neural crest cells specify at the border of the neural plate and non-neural ectoderm after gastrulation. During neurulation, the borders of the neural plate begin to converge at the dorsal midline to form the neural tube. Subsequently, neural crest cells from the

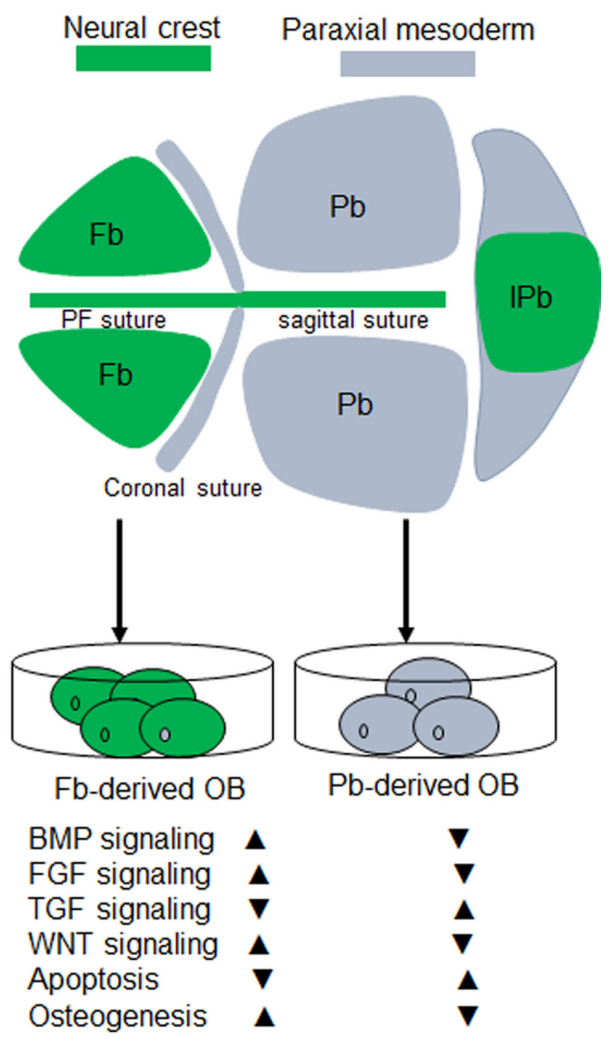

Fig. 1. Diagram of tissue origins in the skull vault and distinct features of tissue-derived osteoblasts activities. Frontal bone-derived osteoblasts showed higher activities of several signaling pathway including BMP, FGF and Wnt, but lower activities of TGF signaling and apoptosis compared to parietal bone-derived osteoblasts. Fb, frontal bone; $P b$, parietal bone; $O B$, osteoblast; IPb, interparietal bone; $P F$, parietofrontal. roof plate of the neural tube delaminate from the neuroepithelium and migrate into different locations of the body through a definable pathway towards their destinations (Chen et al., 2017, Huang and Saint-Jeannet, 2004).

Cell fate mapping using a NC-specific promoter has facilitated genetic labeling of NC cells and their derivatives. Multiple Cre transgenic mouse lines have been generated using a NC marker gene promoter, e.g., Wnt1-Cre, P0-Cre, Dhh-Cre, Pax3-Cre, HtPA-Cre, Sox10-Cre, Sox10ER(T2) CreER(T2), Mef2c-F10NCre. Among them, Wnt1-Cre and PO-Cre lines have been widely used. The Wnt1-Cre model is currently the gold standard for NC lineage. However, Wnt1-Cre-labeled cells in the neural tube, which are not neural crest-derived, and Wnt1-Cre transgene causes ectopic activation of Wnt signaling, which induces defective midbrain development (Lewis et al., 2013). For PO-Cre line, it has been challenging to specifically label early neural crest cells (Yamauchi et al., 1999). Our recent evidence shows that the PO-Cre transgenic model specifically labels neural crest cells at an early stage. We also found a profound and unrecognized difference in the Cre distribution within the midbrain labeled by Wnt1-Cre compared to an extensive labeling within the hindbrain by PO-Cre (Chen et al., 2017) (Fig. 2). This may be the reason why different conclusions have been made using PO-Cre and Wnt1-Cre in labeling CNC (Barriga et al., 2015).

\section{Neural crest patterning during skull development}

A gene regulatory network has been potentially revealed in NC patterning, and a diverse set of interacting signals, transcription factors, and downstream effector genes are involved in the different stages of NC development (Meulemans and Bronner-Fraser, 2004). Genetic approaches in human, fish, chicken, and mice have shown that some genes that specify the complex morphology of the vertebrate skull are similar and therefore a precise shape and position of every skull vault has developed in the vertebrate. Transgenic mouse models provide a useful tool for genetic manipulation of neural-crest-derived components during embryogenesis. We here try to summarize recent findings that associated with skull development and then propose a model for how potential gene regulatory network may function in mouse skull vault (Fig. 3).

\section{Neural fold specification and neural crest induction}

Neural tube closure and neural crest delamination are transient and dynamic. How these critical steps orchestrate timely and spatially are very intriguing. Although the detailed mechanism is not clear, recent findings provide valuable information to better understand their regulations and functions. Wnt signaling, BMP signaling, and $\mathrm{SHH}$ signaling pathways are induced early in neural fold specification. Sensing the gradients of Shh signaling is important for neural tube closure (Balaskas et al., 2012), and Shh acts as a survival factor to mediate CDO (cell-adhesion moleculerelated/downregulated by oncogenes) which is a pro-apoptotic in the developing neural tube (Delloye-Bourgeois et al., 2014). FGF3 regulates BMP signaling in the neuroepithelium, which in turn regulates neural tube closure (Anderson et al., 2016). In addition, Geminin is required for neural tube patterning (Patterson et al., 2014), and Lbx1 promotes neural tube closure (Kruger et al., 2002), while Pax-3 and Pax-7 genes specify dorsal fate in the vertebrate neural tube (Wada et al., 1997). 
Specification of the neural tube is essential for the induction of the neural crest. Several neural crest specifiers have been identified to be critical in neural crest cell induction, such as the ZIC family, TFAP2, Msx1/2, SOX9/10, Snail1/2, Pax3/7, and Myc (Rogers et al., 2012, Stuhlmiller and Garcia-Castro, 2012). In a recent publication visualizing the gene expression pattern in the frontal and parietal compartment in humans showed that only TFAP2 is highly expressed in the neural crest-derived frontal bone (Homayounfar et al., 2015). Our recent data shows that both TFAP2 and SOX10 are highly expressed in the neural crest-derived frontal bone tissue in mouse. This suggests a distinct regulation of different specifiers in neural crest-derived tissues in a species-dependent manner, such as in chicken, SOX10 and SOX9 are regarded as the earliest neural crest-specifying gene (Betancur et al., 2010). However, how these neural crest specifier genes control or guide the cell behavior towards skull development are not clear. One possible explanation is that they co-occupy the promoters of critical regulatory genes related with craniofacial development (Miranda et al., 2017).

\section{Epithelial-mesenchyme transition (EMT) for neural crests}

When the identities of neural crest cells are established, neural crest cells will undergo dynamic transformation from epithelium to mesenchyme. Cell-cell junctions and potential space for cell-cell contacts are required for the transition. Some genes are crucially involved in the regulations of junctions: FoxD3 and Snail downregulate expressions of the molecules associated with epithelial cells
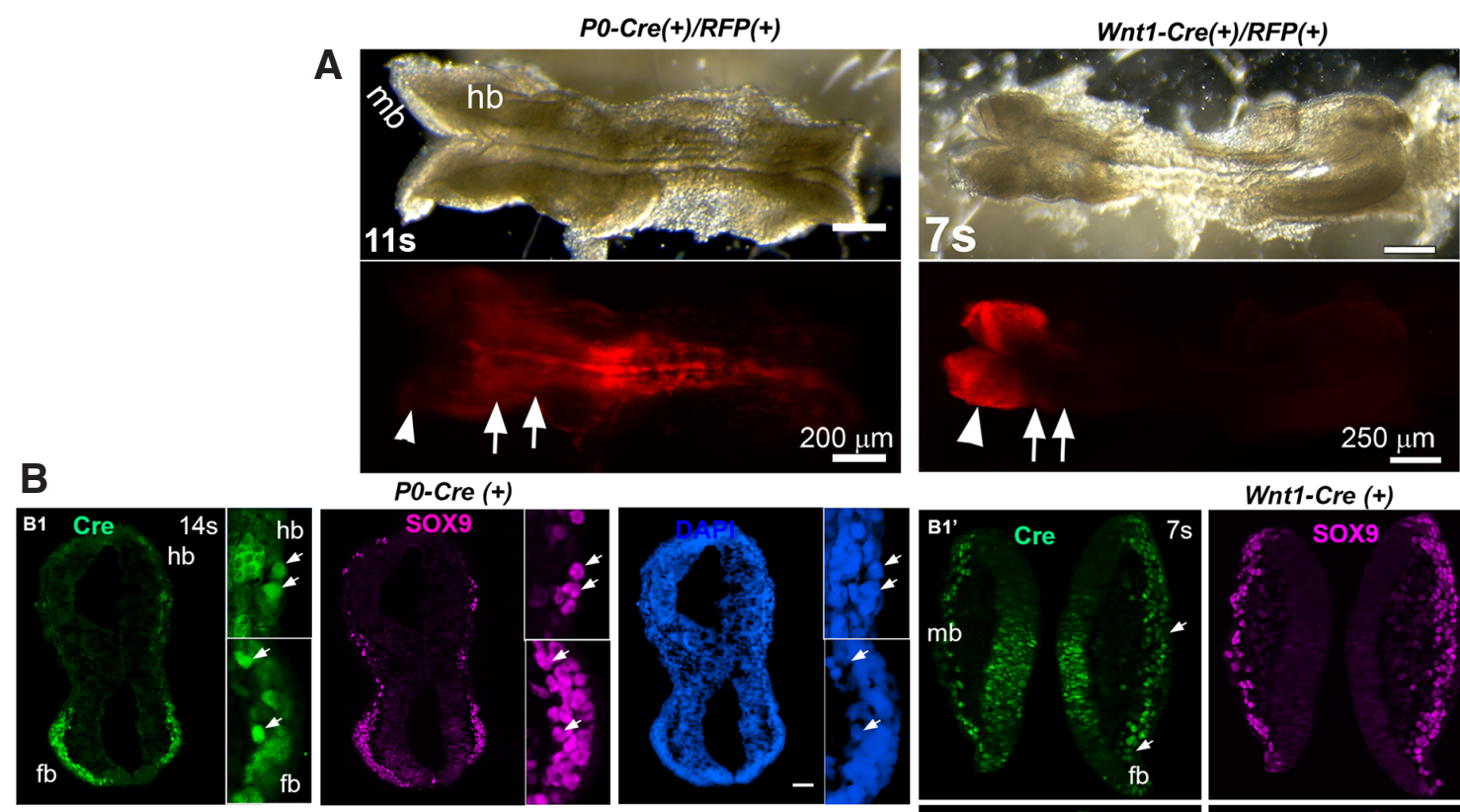

Wnt1-Cre (+)
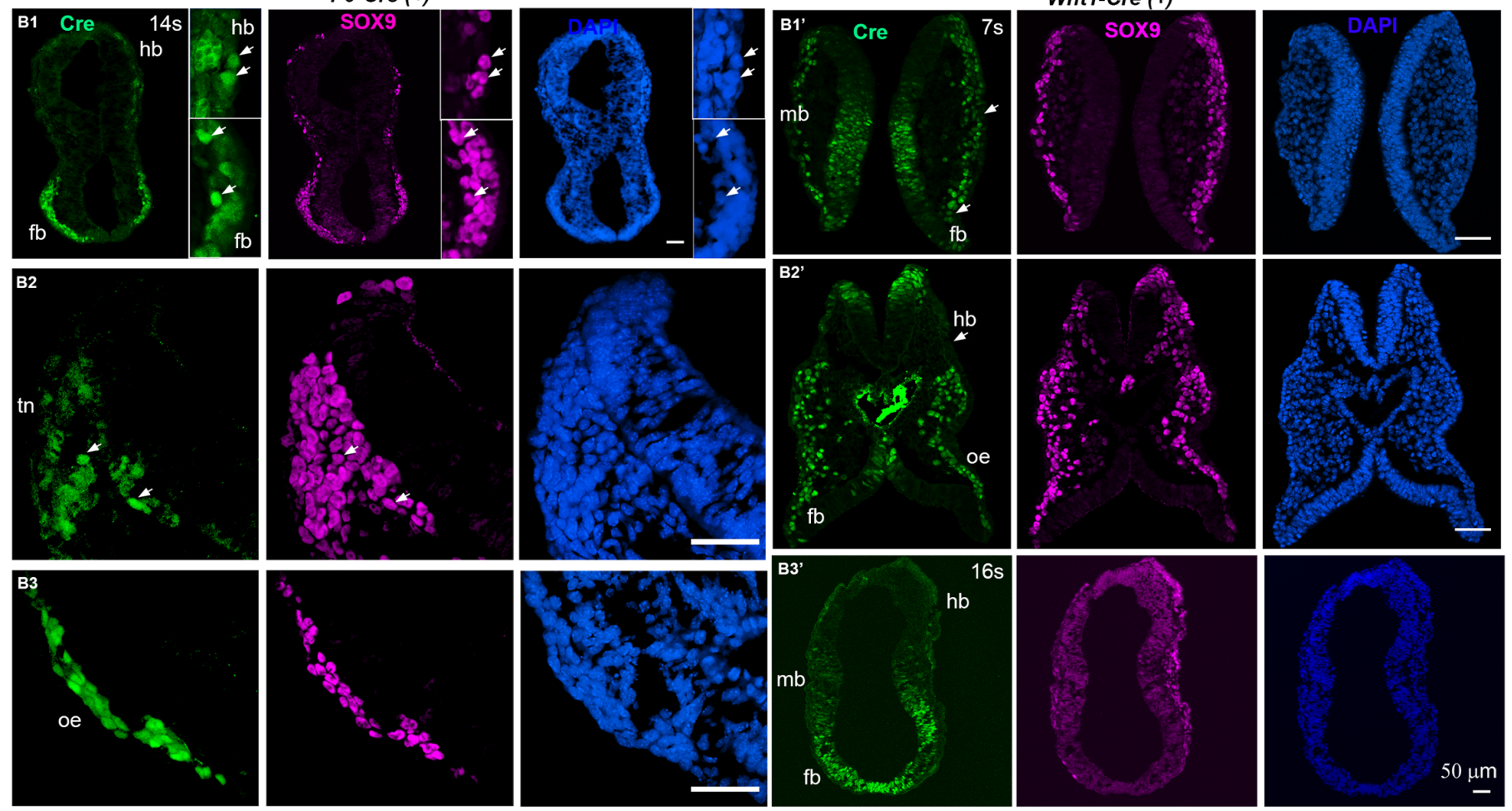

Fig. 2. Differences in neural crest cell labeling using P0-Cre and Wnt1-Cre at E8.5 (modified from our publication, Chen et al., 2017). (A) P0-Cre/RFP labels the hindbrain region (arrow) but not midbrain region (arrowhead) at 11 somite at E8.5, while Wnt1-Cre/RFP labels midbrain region (arrowhead) but spares the hindbrain region (arrow). (B) P0-Cre embryos showed abundant Cre immunostaining signals in hindbrain (hb) and forebrain region (fb) at 14 somite (B1), post-migratory NC cells in trigeminal neural crest (tn, B2) at posterior hindbrain level, and in the optic eminence (oe, B3), in anterior hindbrain (hb, B3). Wnt1-Cre activities were extensive at 7-somite stage (B1'-2'), in the pre-and post-migratory neural crest cells in midbrain (mb, B1') and forebrain (fb, B2'-3') regions, optic eminence (oe, B2') but sparse in hindbrain (hb, B2'). Scale bars: $250 \mu \mathrm{m}$ in (A) and $50 \mu \mathrm{m}$ in (B). 
such as N-cad and E-cad or Cad6B, while upregulate mesenchymal migratory proteins such as Cad7. Cad6B inhibits beta-catenin signaling and affects NC delamination (Rabadan et al., 2016). Snail downregulates tight junctions to allow for the upregulation of gap junctions (Taneyhill et al., 2007). p53 is reported to regulate EMT, and p53 mutants display broad craniofacial defects in skeletal bone (Rinon et al., 2011). GTPases (Faure and Fort, 2015) and Sox2 (Mandalos et al., 2014) function during epithelial to mesenchymal transitions. Besides, ERK-dependent epigenetic signaling results in a gene expression program which is essential for driving EMT (Navandar et al., 2017). Interestedly, some miRNAs are also functional to the developmental EMT (Banerjee et al., 2016). However, how the direction of delaminating neural crest is determined and then follows a certain pathway into different locations of the body remains to be understood.

\section{Neural crest proliferation and apoptosis}

Neural crest specifiers are important in cell proliferation. Protooncogene c-myc deficiency driven by Wnt1-Cre in the neural crest results in viable adult mice with defective frontal bone (Wei et al., 2007). Low expression of TFAP2 leads to reduced cell proliferation (Pfisterer et al., 2002). In SOX10 mutant mice, apoptosis increased in the sites of early neural crest cell development (Kapur, 1999). This well explains that higher expression levels of TFAP2 and SOX10 within frontal bone in mouse may contribute to a high potential for proliferation of neural crest-derived frontal bone. In addition, mouse Foxd3 is essential in maintaining the proliferating and self-renewing population of progenitor cells for neural crest (Hanna et al., 2002). Proliferation and apoptosis is evolutionarily balanced during neural crest development, such as apoptosis in the odd-numbered rhombomeres is needed to eliminate the migration of $r 3$ and $r 5$ crest into first and third arches and therefore avoid extra neural crest-derived muscle attachment at these sites (Ellies et al., 2002).

TGF and WNT signaling pathways are also involved in neural crest proliferation and apoptosis. Deletion of adenomatous polyposis coli (APC), which downregulates Wnt signaling, leads to massive apoptosis of cranial neural crest cells which further results in craniofacial defects (Hasegawa et al., 2002). TGF-beta-activated kinase 1 (Tak1)-deficient mutants display a round skull, hypoplastic maxilla and mandible (Yumoto et al., 2013). Moreover, the Hippo signaling pathway is well known for its role in cell proliferation and growth. Conditional deletion of Yap and Taz in the CNC, two components for Hippo signaling pathway, using Wnt1-Cre and Wnt1-(Cre2SOR) result in enlarged CNC and reduced proliferation in the branchial arch mesenchyme (Wang et al., 2016). Rho kinase (Rock) in mouse is crucial for the survival of NCC to form the craniofacial region (Phillips et al., 2012).

Some genes and transcriptional factors specifically regulate neural crest proliferation and apoptosis: Prtg-deficient (protogenin protein) mice show malformation of bones due to increased apoptosis of rostral CNC (Wang et al., 2013). Polycystin-1 (Pkd1) is required for the proliferation of subpopulations of cranial osteochondroprogenitor cells of both mesodermal and neural crest origin during the growth of the skull (Kolpakova-Hart et al., 2008). Deficiencies of Msx1 and Msx2, homeodomain transcription factor, result in defective patterning and survival of the cranial neural crest (Ishii et al., 2005). TALE-class homeodomain transcription factors Meis and Pbx have specific functions in embryogenesis. Conditional inactivation of Meis2 using crest-specific AP2alphaIRES-Cre mouse displays perturbed development of the craniofacial skeleton with severe anomalies in cranial bones (Machon et al., 2015). Furthermore, gap junctions are also necessary for the survival of neural crest cells.

\section{Neural crest migration}

Upon the emigration of neural crest cells from the neural tube, Noggin and Chordin are involved in this process (Anderson et al., 2006). During closure of the neural tube, transcription factor AP2 is prominently expressed in migrating NC from the neural folds,

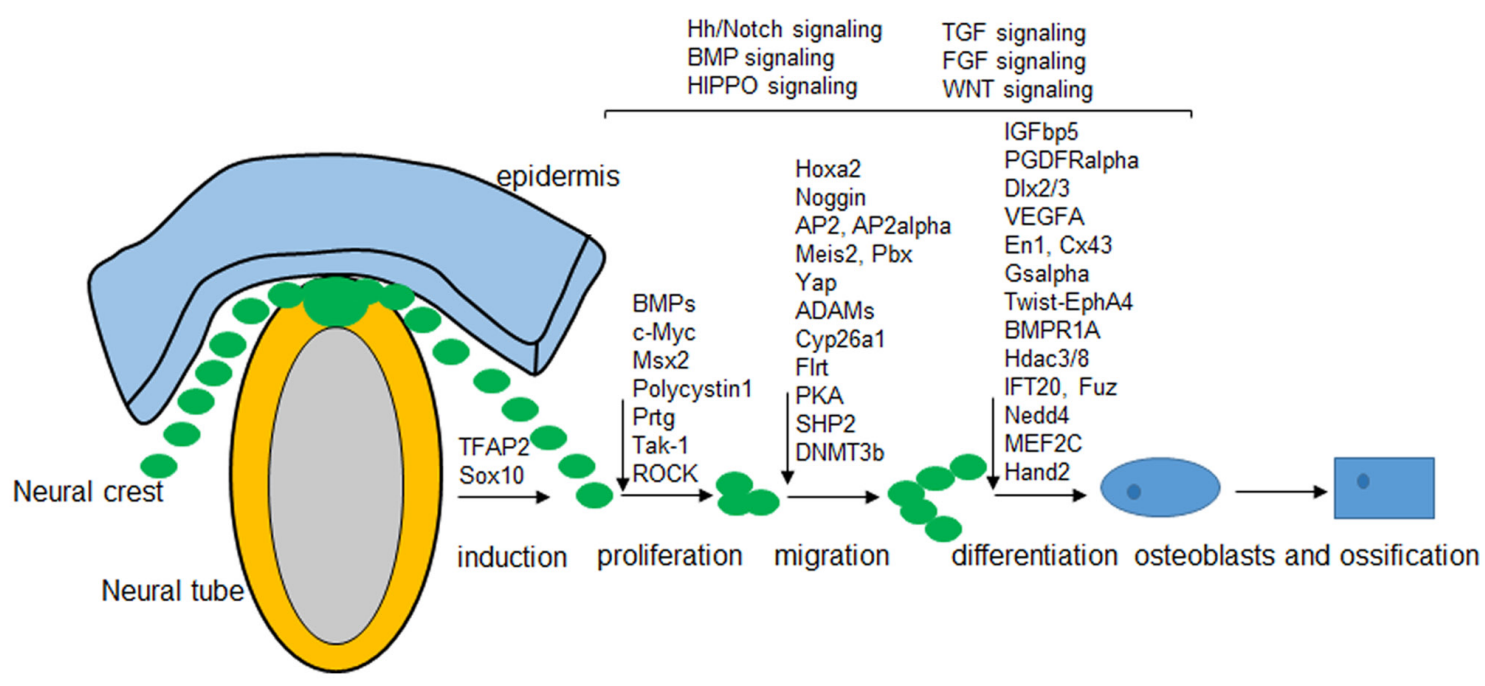

Fig. 3. The proposed gene regulatory network that may be involved in the regulation from neural crest patterning to skull development. Neural crests form at the dorsal part during the closure of the neural tube. Specified neural crest cells delaminate, proliferate, migrate and differentiate into mesenchyme where they give rise to osteoblasts during skull formation. Identified signaling pathways and genes that function throughout the neural crest patterning are marked. 
and later expressed in the regulatory regions (Enkhmandakh and Bayarsaihan, 2015), where it acts as a non-autonomous factor to induce skeletogenesis. AP2 mutant mice are severely defective in face and skull bone.

Following migration, SOX10 and SOX9 are immediately expressed in migrating neural crest cells in mouse, which is different from that in chicken where ETS1 and SOX9 are pan-neural crest regulators of the migratory CNC (Simoes-Costa et al., 2014). Flrt2 and Flrt3, members of the Fibronectin Leucine-Rich Transmembrane (FIrt) gene family, mediate CNC migration during craniofacial development (Gong et al., 2009). Upon the production of migratory cranial neural crest cells, CYP26A1 and CYP26C1 (Uehara et al., 2007) and transmembrane metalloproteases (ADAMs) (Cousin et al., 2011) act as positive regulators, for example, preventing the shuttle of the cleaved cytoplasmic domain of ADAM13 into the nucleus inhibits CNC cell migration in vivo (Cousin et al., 2011). ADAM13 functions in an autonomous manner to trigger CNC migration during skull development (Cousin et al., 2012).

Ablation of PTPN11 in premigratory neural crest cells, which encodes the protein tyrosine phosphatase (SHP2), contributes to profound skull deficits (Nakamura et al., 2009). A subpopulations of postmigratory CNC have roles in patterning distinct derivatives, such as Hoxa2 (Tavella and Bobola, 2010) acts as a selector gene for patterning of branchial arch structures, and cAMP-dependent protein kinase (protein kinase $A(P K A)$ ) has strict regulation on the derivative patterning (Jones et al., 2010). How these genes and signaling pathways work dynamically and directionally in neural crest migration are intriguing.

\section{Osteogenesis in neural crest}

Some key transcriptional factors play essential roles during osteogenesis in the neural crest: Firstly, Msx2 drives CNC differentiation into the skeletal system. Msx2 mutants are defective in skeletogenic mesenchyme cells. Overexpression of Msx2 in mice leads to the growth of parietal bone into the sagittal suture. Neural crest-specific removal of Msx2 results in a larger defect in the frontal bone (Roybal et al., 2010). An interaction between Msx2 and Twist is needed during the differentiation and proliferation of skeletogenic mesenchyme and formation of skull vault (Bildsoe et al., 2009).

Furthermore, the homeodomain family of transcription factors regulate the development of $\mathrm{CNC}$-derived craniofacial skeleton. DIx2 is expressed in the epithelium and mesenchyme cells within branchial arches. Deletion of Dlx2 leads to skeletal anomalies (McKeown et al., 2005). Mice lacking Dlx3 exhibit alteration of calvaria (Duverger et al., 2013). DIx5 and DIx6 function during craniofacial development, and MEF2C is required for the expressions of DIx5 and DIx6. Transcription factor gene Hand2 is expressed in neural crest-derived mesenchyme cells during the branchial arches (Ruest etal., 2003), suggesting its role in craniofacial development.

Moreover, Connexin43 (Cx43) is required for neural crest cell patterning and ossification. Cx43 mutants show delayed ossification of the cranial vault (Lecanda et al., 2000). Loss of Gsalpha, G-protein alpha-subunit, in neural crest cells does not affect CNC migration or cell proliferation, but significantly accelerates osteochondrogenic differentiation (Lei et al., 2016). Conditionally overexpression of autoactivated platelet-derived growth factor receptor alpha (PDGFRalpha) in neural crest cells enhanced proliferation of osteoprogenitors and accelerated ossification of osteoblasts (Moenning et al., 2009).
Signaling pathways have been extensively studied during the osteogenesis in the neural crest. FGF signaling plays an essential role in the skeletogenic differentiation from the cranial neural crest. Conditional overexpression of the FGFR2 S252W mutation in neural crest-derived tissues causes a more severe craniofacial phenotype (Heuze et al., 2014). Simultaneously, activation of FGFR2 (S252W) is sufficient to cause craniosynostosis (Holmes and Basilico, 2012). Interestingly, a novel skull defect with only a single bone pair is found in Fuz mutant mice and this phenotype can be rescued by loss of one allele of Fgf8 (Tabler et al., 2016). The receptor of FGF signaling regulates homeoprotein engrailed 1 (EN1) during osteogenic differentiation (Deckelbaum et al., 2012). Moreover, Hedgehog signaling $(\mathrm{Hh})$ is also critical for neural crest patterning: Shh promotes survival of neural crest cells to colonize in the first branchial arch (Delloye-Bourgeois et al., 2014). Disruption of Hh signaling leads to abnormal neural crest development, resulting in malformed skull base. Removing Hh-responsiveness specifically in neural crest cells leads to the absence of many CNC-derived skeletal components (Jeong et al., 2004).

BMP and TGF signaling pathway are also important in osteoblast differentiation and bone formation (Chen et al., 2012). BMPs ligands such as Bmp2 and Bmp7 are required in frontal bone primordium. Inactivation of $\mathrm{Bmp} 2$ and $\mathrm{Bmp} 7$ leads to multiple defective CNC-derived skeletal elements (Bonilla-Claudio et al., 2012). Neural crest-specific deletion of Acvr1, a type I receptor for BMPs, induces craniofacial defects, and deletion of another type I receptor, Bmpr1a, causes mid-gestation lethality (Stottmann et al., 2004). Constitutive overexpression of Bmpr1a in neural crest cells leads to premature suture fusion in mice (Komatsu et al., 2013). TGF-beta signaling regulates the fate of neural crest cells. Mice with neural crest-specific deletion of TGF-beta receptor 2 (Tgfbr2) show craniofacial skeletal malformations (Ho et al., 2015). TGF-beta mediates Msx2 expression during skull development. Msx2 is regulated by BMP-Smad signaling pathway, and Twist1 is a downstream target of Wnt signaling. In short, these interactions suggest integrated functions of the different signaling pathways during osteogenesis in the neural crest.

\section{Epigenetic regulation}

Histone deacetylases (Hdacs), transcriptional repressors, displays essential roles in neural crest cell patterning. Hdac8 represses a subset of transcription factors in CNC, such as Otx2 and Lhx1, and thereby specifically influences the patterning of the skull. Hdac8 mutant mice are perinatally lethal due to skull instability (Haberland et al., 2009). Hdac3 is needed for neural crest cells during craniofacial development. Conditionally knockout Hdac3 in the neural crest reveals fully penetrant craniofacial abnormalities and upregulates Msx1, Msx2, and Bmp4 expression in the mesenchyme, suggesting that Hdac3 serves as a critical regulator for craniofacial morphogenesis (Singh et al., 2013). In addition, mutation of de novo DNA methyltransferase DNMT3b leads to defects in neural crest-derived craniofacial skeleton (Jacques-Fricke et al., 2012).

\section{Ubiquitination}

Wwp2 E3 ubiquitin ligase works with paired-like homeobox transcription factor Goosecoid (Gsc) during craniofacial development. Gsc is activated by the APC (Cdh1) E3 ubiquitin ligase. Conditional deletion of neural crest-specific Cdh1 gene causes bone malformation that is similar to Wwp2-deficient mice with a 
domed skull displaying a short snout and a twisted nasal bone (Shao et al., 2016). Mice with specific ablation of another E3 ubiquitin ligase, Nedd4, in neural crest cells or osteoblasts exhibit profound craniofacial defects with marked reduction of cranial bone (Wiszniak et al., 2016).

\section{Primary cilium-related regulation}

The primary cilium is a cellular microtubule-based organelle that is important for cell proliferation, differentiation, survival, and homeostasis. Intraflagellar transport (IFT) functions in assembling primary cilia, such as IFT20 and IFT88. Deletion of IFT20 in neural crest cells leads to skeletal dysplasia, such as osteopenia in the facial region (Noda et al., 2016). Deletion of IFT88 results in a decrease in neural crest cell proliferation at early stages (Tian et al., 2017). Polycystin 2 (Pkd2) localized in primary cilia, and conditional deletion of $\mathrm{Pkd} 2$ in neural crest-derived cells causes malformed skull shapes (Khonsari et al., 2013). Kif3a is the motor protein within primary cilia. Conditional deletion of Kif3a in neural crest cells has a dramatic effect on intramembranous ossification, and Shh signaling is disrupted in Kif3a-deficient neural crest-derived mesenchymal cells (Kolpakova-Hart et al., 2007). However, ciliary proteins EVC and EVC2, which are regarded as causative genes and having an important role in transduction of Hedgehog signaling, do not show observed defects in skull development but defects in incisor growth using neural crestspecific mouse model (Zhang et al., 2015).

\section{Human diseases or disorders from defective neural crest patterning}

Disruption or perturbation of the patterning on neural crest cells leads to defective organs and tissues. Some human diseases or disorders stem from abnormal neural crest patterning (Table 1). Treacher Collins syndrome is an autosomal dominant congenital disorder which is characterized by craniofacial deformities, such as facial bones. The prevalence of this disease is about 1:10,00050,000 individuals. Loss of TCOF1 encoding TREACLE protein affects the craniofacial skeleton (van Gijn et al., 2013). Premature fusion of the calvarial bones leads to craniosynostosis, a relatively common pediatric disease with occurrence in 1:2500 births. A variety of genetic lesions can result in craniosynostosis, such as gain-of-function of FGFR1-3 and loss-of-function of TWIST1 (Holmes and Basilico, 2012). Disruption of cranial neural crest migration and survival can cause human disease, such as mutation of MID1 gene results in X-linked Opitz syndrome (XLOS) with an estimated prevalence of 1:50,000-100, 000 male individuals and the patients exhibit midline malformation with distinct craniofacial abnormalities such as wide-spaced eyes (Latta and Golding, 2012). Disrupted migration of neural crest cells with mutation of ephrin-B1 gene (EFNB1) lead to craniofrontonasal syndrome (CFNS), which is very rare inherited X-linked disorders with estimated birth prevalence of 1:120,000. Multiple defects were observed including asymmetry, midline defects, skeletal abnormalities, and unusual head shape (Wieacker and Wieland, 2005). A novel mutation in Zfhx1b gene in neural crest precursor cells in mouse can lead to Mowat-Wilson syndrome, a genetic disorder with distinct facial features and an unusual small head (Van de Putte et al., 2007). Abnormal development of neural crest cells can result in a genetic disorder called Axenfeld-Rieger syndrome (ARS). ARS occurrence is about 1:200,000 individuals and eye development exhibits major disorder. PITX2 and FOXC1 are the leading causes of the disease.

Magnetic resonance imaging is a valuable tool to show multiple defects including the defective skull base (Whitehead et al., 2013). SHP2 contributes to higher occurrence of Noonan syndrome disease, a genetic disorder characterizing by defective cardiac and craniofacial developments with estimated prevalence of 1:1000-1:2500 live births. SHP2 plays an essential role for CNC normal migration and differentiation into diverse lineages of the heart and skull (Nakamura et al., 2009). However, the symptoms improve with age and most adults suffering NS do not need special medical care. Mutations from several genes have been associated with NS disease such as in KRAS, RAF1 and SOS1RIT1 (van Trier et al., 2016).

\section{Neural crest cells and regenerative medicine}

Defective neural crest patterning results in severe birth defects, which may require a comprehensive surgery and rehabilitation at tremendous economic burden. Findings based on genetic mouse models are valuable to understand the regulation of genes and signaling pathway during skull development. This will potentially help to determine a target molecule that promotes the differentiation of neural crest cells to osteoblasts while maintains the superior osteogenic potential and bone regeneration potential compared to mesoderm-derived bone tissues, which are important for regenerative medicine in clinic.

Endogenous calvarial regeneration may be a promising solution for craniofacial reconstruction (Senarath-Yapa et al., 2013), and a molecule or agent will be found to sufficiently drive endogenous bone formation. Similarly, fibronectin, which is involved in mediating differentiation of the skull and migration of neural crest cells, works as a carrier for BMPs and used as an essential component in stem cell technology associated with craniofacial

TABLE 1

HUMAN DISEASES OR DISORDERS FROM DEFECTIVE NEURAL CREST PATTERNING

\begin{tabular}{|c|c|c|c|c|}
\hline Genes & Disease & Prevalence & Some symptoms & Reference \\
\hline TCOF1 & Treacher Collins syndrome & $1: 10,000-50,000$ & Craniofacial skeleton & (van Gijn et al., 2013) \\
\hline FGFR1-3, Twist1 & craniosynostosis & $1: 2500$ & Premature fusion of skull & (Holmes and Basilico, 2012) \\
\hline MID1 & X-linked Opitz syndrome & $1: 50,000-1: 100,000$ & Craniofacial abnormalities & (Latta and Golding, 2012) \\
\hline EFNB1 & craniofrontonasal syndrome & $1: 120,000$ & Asymmetry, midline defects, skeletal abnormalities & (Wieacker and Wieland, 2005) \\
\hline Zfhx1b & Mowat-Wilson syndrome & Not sure & Facial defects, unusual small head & (Van de Putte et al., 2007) \\
\hline PITX2, FOXC1 & Axenfeld-Rieger syndrome & $1: 200,000$ & Defective eye, defective skull base & (Whitehead et al., 2013) \\
\hline PTPN11, KRAS, RAF1 & Noonan syndrome & 1:1000-1:2500 live births & Defective cardiac and craniofacial developments & (van Trier et al., 2016) \\
\hline
\end{tabular}


surgery (Al-Qattan et al., 2014, Brunskill et al., 2014).

Engineering cranial neural crest cells is also a tool to treat diseases. Patient-derived CNC cells can manipulate bone formation in vitro, which can be used for transplantation. CNC have been successfully differentiated into osteoblasts in vitro, e.g. in a 3D bioengineering microenvironment where neural crest cells are encapsulated in gelatin-based photo-cross-linkable hydrogels and cultured for about 3 weeks to efficiently drive differentiation (Namkoong et al., 2016). In addition, CNCs supplemented with BMP4 in the culture media are capable of differentiating into osteocytes and chondrocytes (Mimura et al., 2016). Mouse embryonic stem cells can be selectively differentiated into cranial NC stem cells, which can further differentiate into other cell types including osteoblasts (Minamino etal., 2015). IPSCs are another useful tool for genetic manipulation of certain cell types in vitro. Skin-derived precursors can be differentiated into the neural crest lineage, which can be subsequently propagated and directed towards the mesenchymal lineages, such as osteogenic cells (Kang et al., 2011). Collectively, these examples demonstrate that neural crest cells are an accessible and potentially autologous source for tissue engineering and bone repair. Further researches will assure that the engineered neural crest cells can be delivered in a safe way, homed sufficiently, and functioned properly in vivo.

\section{Summary}

Researches understanding neural crest pattering have made great progress in recent years, which lead to a better understanding about its patterning, development, and regulation. Yet, new technologies are needed that can be widely used to further our understanding, especially under the serious reality that more than $30 \%$ of birth defects are involved in defective a head or face, and the craniofacial abnormalities are a primary cause of infant mortality. Translating novel findings into the clinic remains to be shown in the future. Timely diagnosis, disease prevention and treatment options are unsolved issues. Major progress in culturing cranial neural crest cells have been made, so that differentiation of neural crest cells into different cell types is invaluable for cell therapy or tissue repair in clinic in the coming future.

We here review the most recent findings regarding neural crest patterning and its potential relationship to the development of skull. We propose that a gene regulatory network is essential to maintain the superior regenerative capacity in neural crestderived frontal bone. Visualizing the regulatory network in neural crest patterning during skull development will be important to understand how signaling pathways are coordinated to regulate osteoblast activities. This evolutional model of the skull vault involving dual tissue origins provides some cues that need to be dissected, which in turn will be beneficial to not only the regulation of bone biology but also their regenerative applications in clinic.

\section{Conflict of interest}

The Authors declare no conflict of interest.

\section{Acknowledgements}

The work is supported by grants by National Natural Science Foundation of China (No. 81400489; No. 81501882). Thanks to Dr. Marietta Zille (Cornell University) for her critical review and suggestions. We apologize to the many researchers whose work could not be cited due to space limitations.

\section{References}

AL-QATTAN, M.M., ALSHOMER, F., ALQAHTANI, A. and ALHADLG, A. (2014). Fibronectin and craniofacial surgery. Ann Plast Surg 73: 716-720.

ANDERSON, M.J., SCHIMMANG, T. and LEWANDOSKI, M. (2016). An FGF3-BMP Signaling Axis Regulates Caudal Neural Tube Closure, Neural Crest Specification and Anterior-Posterior Axis Extension. PLoS Genet 12: e1006018:1-30

ANDERSON, R.M., STOTTMANN, R.W., CHOI, M. and KLINGENSMITH, J. (2006). Endogenous bone morphogenetic protein antagonists regulate mammalian neural crest generation and survival. Dev Dyn 235: 2507-2520.

BALASKAS, N., RIBEIRO, A., PANOVSKA, J., DESSAUD, E., SASAI, N., PAGE, K.M., BRISCOE, J. and RIBES, V. (2012). Gene regulatory logic for reading the Sonic Hedgehog signaling gradient in the vertebrate neural tube. Cell 148: 273-284.

BANERJEE, P., DUTTA, S. and PAL, R. (2016). Dysregulation of Wnt-Signaling and a Candidate Set of miRNAs Underlie the Effect of Metformin on Neural Crest Cell Development. Stem Cells 34: 334-345.

BARRIGA, E.H., TRAINOR, P.A., BRONNER, M. and MAYOR, R. (2015). Animal models for studying neural crest development: is the mouse different? Development 142: 1555-1560

BEHR, B., PANETTA, N.J., LONGAKER, M.T. and QUARTO, N. (2010). Different endogenous threshold levels of Fibroblast Growth Factor-ligands determine the healing potential of frontal and parietal bones. Bone 47: 281-294.

BETANCUR, P., BRONNER-FRASER, M. and SAUKA-SPENGLER, T. (2010). Genomic code for Sox10 activation reveals a key regulatory enhancer for cranial neural crest. Proc Natl Acad Sci USA 107: 3570-3575.

BILDSOE, H., LOEBEL, D.A., JONES, V.J., CHEN, Y.T., BEHRINGER, R.R. and TAM, P.P. (2009). Requirement for Twist1 in frontonasal and skull vault development in the mouse embryo. Dev Biol 331: 176-188.

BONILLA-CLAUDIO, M., WANG, J., BAI, Y., KLYSIK, E., SELEVER, J. and MARTIN, J.F. (2012). Bmp signaling regulates a dose-dependent transcriptional program to control facial skeletal development. Development 139: 709-719.

BRUNSKILL, E.W., POTTER, A.S., DISTASIO, A., DEXHEIMER, P., PLASSARD, A., ARONOW, B.J. and POTTER, S.S. (2014). A gene expression atlas of early craniofacial development. Dev Biol 391: 133-146.

CHEN, G., DENG, C. and LI, Y.P. (2012). TGF-beta and BMP signaling in osteoblast differentiation and bone formation. Int J Biol Sci 8: 272-288.

CHEN, G., ISHAN, M., YANG, J., KISHIGAMI, S., FUKUDA, T., SCOTT, G., RAY, M.K., SUN, C., CHEN, S., KOMATSU, Y. et al., (2017). Specific and spatial labeling of P0-Cre versus Wnt1-Cre in cranial neural crest in early mouse embryos. Genesis. e23034:1-19

COUSIN, H., ABBRUZZESE, G., KERDAVID, E., GAULTIER, A. and ALFANDARI, D. (2011). Translocation of the cytoplasmic domain of ADAM13 to the nucleus is essential for Calpain8-a expression and cranial neural crest cell migration. Dev Cell 20: 256-263.

COUSIN, H., ABBRUZZESE, G., MCCUSKER, C. and ALFANDARI, D. (2012) ADAM13 function is required in the 3 dimensional context of the embryo during cranial neural crest cell migration in Xenopus laevis. Dev Biol 368: 335-344.

DECKELBAUM, R.A., HOLMES, G., ZHAO, Z., TONG, C., BASILICO, C. and LOOMIS, C.A. (2012). Regulation of cranial morphogenesis and cell fate at the neural crest-mesoderm boundary by engrailed 1. Development 139: 1346-1358.

DELLOYE-BOURGEOIS, C., RAMA, N., BRITO, J., LE DOUARIN, N. and MEHLEN P. (2014). Sonic Hedgehog promotes the survival of neural crest cells by limiting apoptosis induced by the dependence receptor CDON during branchial arch development. Biochem Biophys Res Commun 452: 655-660.

DUVERGER, O., ISAAC, J., ZAH, A., HWANG, J., BERDAL, A., LIAN, J.B. and MORASSO, M.I. (2013). In vivo impact of DIx3 conditional inactivation in neural crest-derived craniofacial bones. J Cell Physiol 228: 654-664.

ELLIES, D.L., TUCKER, A.S. and LUMSDEN, A. (2002). Apoptosis of premigratory neural crest cells in rhombomeres 3 and 5 : consequences for patterning of the branchial region. Dev Biol 251: 118-128.

ENKHMANDAKH, B. and BAYARSAIHAN, D. (2015). Genome-wide Chromatin Mapping Defines AP2alpha in the Etiology of Craniofacial Disorders. Cleft Palate Craniofac J 52: 135-142

FAURE, S. and FORT, P. (2015). Atypical RhoV and RhoU GTPases control development of the neural crest. Small GTPases 6: 174-177. 
GONG, S.G., MAI, S., CHUNG, K. and WEI, K. (2009). Flrt2 and Flrt3 have overlapping and non-overlapping expression during craniofacial development. Gene Expr Patterns 9: 497-502.

HABERLAND, M., MOKALLED, M.H., MONTGOMERY, R.L. and OLSON, E.N. (2009). Epigenetic control of skull morphogenesis by histone deacetylase 8 . Genes Dev 23: 1625-1630.

HANNA, L.A., FOREMAN, R.K., TARASENKO, I.A., KESSLER, D.S. and LABOSKY, P.A. (2002). Requirement for Foxd3 in maintaining pluripotent cells of the early mouse embryo. Genes Dev 16: 2650-2661.

HASEGAWA, S., SATO, T., AKAZAWA, H., OKADA, H., MAENO, A., ITO, M., SUGITANI, Y., SHIBATA, H., MIYAZAKI JI, J., KATSUKI, M. et al., (2002). Apoptosis in neural crest cells by functional loss of APC tumor suppressor gene. Proc Natl Acad Sci USA 99: 297-302.

HEUZE, Y., SINGH, N., BASILICO, C., JABS, E.W., HOLMES, G. and RICHTSMEIER, J.T. (2014). Morphological comparison of the craniofacial phenotypes of mouse models expressing the Apert FGFR2 S252W mutation in neural crest- or mesoderm-derived tissues. Bone 63: 101-109.

HO, T.V., IWATA, J., HO, H.A., GRIMES, W.C., PARK, S., SANCHEZ-LARA, P.A. and CHAl, Y. (2015). Integration of comprehensive 3D microCT and signaling analysis reveals differential regulatory mechanisms of craniofacial bone development. Dev Biol 400: 180-190.

HOLMES, G. and BASILICO, C. (2012). Mesodermal expression of Fgfr2S252W is necessary and sufficient to induce craniosynostosis in a mouse model of Apert syndrome. Dev Biol 368: 283-293.

HOMAYOUNFAR, N., PARK, S.S., AFSHARINEJAD, Z., BAMMLER, T.K., MACDONALD, J.W., FARIN, F.M., MECHAM, B.H. and CUNNINGHAM, M.L. (2015). Transcriptional analysis of human cranial compartments with different embryonic origins. Arch Oral Biol 60: 1450-1460.

HUANG, X. and SAINT-JEANNET, J.P. (2004). Induction of the neural crest and the opportunities of life on the edge. Dev Biol 275: 1-11.

ISHII, M., HAN, J., YEN, H.Y., SUCOV, H.M., CHAI, Y. and MAXSON, R.E., JR. (2005). Combined deficiencies of Msx 1 and Msx2 cause impaired patterning and survival of the cranial neural crest. Development 132: 4937-4950.

JACQUES-FRICKE, B.T., ROFFERS-AGARWAL, J. and GAMMILL, L.S. (2012). DNA methyltransferase $3 \mathrm{~b}$ is dispensable for mouse neural crest development. PLoS One 7: e47794:1-9

JEONG, J., MAO, J., TENZEN, T., KOTTMANN, A.H. and MCMAHON, A.P. (2004). Hedgehog signaling in the neural crest cells regulates the patterning and growth of facial primordia. Genes Dev 18: 937-951.

JIANG, X., ISEKI, S., MAXSON, R.E., SUCOV, H.M. and MORRISS-KAY, G.M. (2002). Tissue origins and interactions in the mammalian skull vault. Dev Biol241:106-116.

JONES, G.N., PRINGLE, D.R., YIN, Z., CARLTON, M.M., POWELL, K.A., WEINSTEIN, M.B., TORIBIO, R.E., LA PERLE, K.M. and KIRSCHNER, L.S. (2010). Neural crest-specific loss of Prkar1a causes perinatal lethality resulting from defects in intramembranous ossification. Mol Endocrinol 24: 1559-1568.

KANG, H.K., MIN, S.K., JUNG, S.Y., JUNG, K., JANG, D.H., KIM, O.B., CHUN, G.S., LEE, Z.H. and MIN, B.M. (2011). The potential of mouse skin-derived precursors to differentiate into mesenchymal and neural lineages and their application to osteogenic induction in vivo. Int $\mathrm{J} \mathrm{Mol} \mathrm{Med} \mathrm{28:} \mathrm{1001-1011.}$

KAPUR, R.P. (1999). Early death of neural crest cells is responsible for total enteric aganglionosis in Sox10(Dom)/Sox10(Dom) mouse embryos. Pediatr Dev Pathol 2: 559-569.

KHONSARI, R.H., OHAZAMA, A., RAOUF, R., KAWASAKI, M., KAWASAKI, K., PORNTAVEETUS, T., GHAFOOR, S., HAMMOND, P., SUTTIE, M., ODRI, G.A. et al., (2013). Multiple postnatal craniofacial anomalies are characterized by conditional loss of polycystic kidney disease 2 (Pkd2). Hum Mol Genet 22: 1873-1885.

KOLPAKOVA-HART, E., JINNIN, M., HOU, B., FUKAI, N. and OLSEN, B.R. (2007). Kinesin-2 controls development and patterning of the vertebrate skeleton by Hedgehog- and Gli3-dependent mechanisms. Dev Biol 309: 273-284.

KOLPAKOVA-HART, E., MCBRATNEY-OWEN, B., HOU, B., FUKAI, N., NICOLAE, C., ZHOU, J. and OLSEN, B.R. (2008). Growth of cranial synchondroses and sutures requires polycystin-1. Dev Biol 321: 407-419.

KOMATSU, Y., YU, P.B., KAMIYA, N., PAN, H., FUKUDA, T., SCOTT, G.J., RAY, M.K., YAMAMURA, K. and MISHINA, Y. (2013). Augmentation of Smad-dependent BMP signaling in neural crest cells causes craniosynostosis in mice. $J$ Bone Miner Res 28: 1422-1433.
KOYABU, D., MAIER, W. and SANCHEZ-VILLAGRA, M.R. (2012). Paleontologica and developmental evidence resolve the homology and dual embryonic origin of a mammalian skull bone, the interparietal. Proc NatIAcad SciUSA 109: 14075-14080.

KRUGER, M., SCHAFER, K. and BRAUN, T. (2002). The homeobox containing gene $L b x 1$ is required for correct dorsal-ventral patterning of the neural tube. $J$ Neurochem 82: 774-782.

LATTA, E.J. and GOLDING, J.P. (2012). Regulation of PP2A activity by Mid1 controls cranial neural crest speed and gangliogenesis. Mech Dev 128: 560-576.

LECANDA, F., WARLOW, P.M., SHEIKH, S., FURLAN, F., STEINBERG, T.H. and CIVITELLI, R. (2000). Connexin43 deficiency causes delayed ossification, craniofacial abnormalities, and osteoblast dysfunction. J Cell Biol 151: 931-944.

LEI, R., ZHANG, K., WEI, Y., CHEN, M., WEINSTEIN, L.S., HONG, Y., ZHU, M., LI, H. and $\mathrm{LI}, \mathrm{H}$. (2016). G-Protein alpha-Subunit Gsalpha Is Required for Craniofacial Morphogenesis. PLoS One 11: e0147535:1-21

LEWIS, A.E., VASUDEVAN, H.N., O'NEILL, A.K., SORIANO, P. and BUSH, J.O. (2013). The widely used Wnt1-Cre transgene causes developmental phenotypes by ectopic activation of Wnt signaling. Dev Biol 379: 229-234.

LI, S., QUARTO, N. and LONGAKER, M.T. (2010). Activation of FGF signaling mediates proliferative and osteogenic differences between neural crest derived frontal and mesoderm parietal derived bone. PLoS One 5: e14033:1-13

LI, S., QUARTO, N., SENARATH-YAPA, K., GREY, N., BAI, X. and LONGAKER, M.T. (2015). Enhanced Activation of Canonical Wnt Signaling Confers MesodermDerived Parietal Bone with Similar Osteogenic and Skeletal Healing Capacity to Neural Crest-Derived Frontal Bone. PLoS One 10: e0138059:1-15

MACHON, O., MASEK, J., MACHONOVA, O., KRAUSS, S. and KOZMIK, Z. (2015). Meis2 is essential for cranial and cardiac neural crest development. BMC Dev Biol 15: 40.

MANDALOS, N., RHINN, M., GRANCHI, Z., KARAMPELAS, I., MITSIADIS, T., ECONOMIDES, A.N., DOLLE, P. and REMBOUTSIKA, E. (2014). Sox2 acts as a rheostat of epithelial to mesenchymal transition during neural crest development. Front Physiol 5: 1-12

MCKEOWN, S.J., NEWGREEN, D.F. and FARLIE, P.G. (2005). DIx2 over-expression regulates cell adhesion and mesenchymal condensation in ectomesenchyme. Dev Biol 281: 22-37.

MEULEMANS, D. and BRONNER-FRASER, M. (2004). Gene-regulatory interactions in neural crest evolution and development. Dev Cell 7: 291-299.

MIMURA, S., SUGA, M., OKADA, K., KINEHARA, M., NIKAWA, H. and FURUE, M.K (2016). Bone morphogenetic protein 4 promotes craniofacial neural crest induction from human pluripotent stem cells. Int J Dev Biol 60: 21-28.

MINAMINO, Y., OHNISHI, Y., KAKUDO, K. and NOZAKI, M. (2015). Isolation and propagation of neural crest stem cells from mouse embryonic stem cells via cranial neurospheres. Stem Cells Dev 24: 172-181.

MIRANDA, P., ENKHMANDAKH, B. and BAYARSAIHAN, D. (2017). TFII-I and AP2alpha Co-occupy the Promoters of Key Regulatory Genes Associated With Craniofacial Development. Cleft Palate Craniofac J. 15:214-224

MOENNING, A., JAGER, R., EGERT, A., KRESS, W., WARDELMANN, E. and SCHORLE, H. (2009). Sustained platelet-derived growth factor receptor alpha signaling in osteoblasts results in craniosynostosis by overactivating the phospholipase C-gamma pathway. Mol Cell Biol 29: 881-891.

NAKAMURA, T., GULICK, J., COLBERT, M.C. and ROBBINS, J. (2009). Protein tyrosine phosphatase activity in the neural crest is essential for normal heart and skull development. Proc Natl Acad Sci USA 106: 11270-11275.

NAMKOONG, B., GUVEN, S., RAMESAN, S., LIAUDANSKAYA, V., ABZHANOV, A and DEMIRCI, U. (2016). Recapitulating cranial osteogenesis with neural crest cells in 3-D microenvironments. Acta Biomater 31: 301-311.

NAVANDAR, M., GARDING, A., SAHU, S.K., PATASKAR, A., SCHICK, S. and TIWARI, V.K. (2017). ERK signalling modulates epigenome to drive epithelial to mesenchymal transition. Oncotarget 8: 29269-29281.

NODA, K., KITAMI, M., KITAMI, K., KAKU, M. and KOMATSU, Y. (2016). Canonical and noncanonical intraflagellar transport regulates craniofacial skeletal development. Proc Natl Acad Sci USA 113: E2589-2597.

PATTERSON, E.S., WALLER, L.E. and KROLL, K.L. (2014). Geminin loss causes neural tube defects through disrupted progenitor specification and neuronal differentiation. Dev Biol 393: 44-56.

PFISTERER, P., EHLERMANN, J., HEGEN, M. and SCHORLE, H. (2002). A subtrac- 
tive gene expression screen suggests a role of transcription factor AP-2 alpha in control of proliferation and differentiation. J Biol Chem 277: 6637-6644.

PHILLIPS, H.M., PAPOUTSI, T., SOENEN, H., YBOT-GONZALEZ, P., HENDERSON, D.J. and CHAUDHRY, B. (2012). Neural crest cell survival is dependent on Rho kinase and is required for development of the mid face in mouse embryos. PLoS One 7: e37685: 1-11

QUARTO, N., BEHR, B., LI, S. and LONGAKER, M.T. (2009). Differential FGF ligands and FGF receptors expression pattern in frontal and parietal calvarial bones. Cells Tissues Organs 190: 158-169.

QUARTO, N., WAN, D.C., KWAN, M.D., PANETTA, N.J., LI, S. and LONGAKER, M.T. (2010). Origin matters: differences in embryonic tissue origin and Wnt signaling determine the osteogenic potential and healing capacity of frontal and parietal calvarial bones. J Bone Miner Res 25: 1680-1694.

RABADAN, M.A., HERRERA, A., FANLO, L., USIETO, S., CARMONA-FONTAINE, C., BARRIGA, E.H., MAYOR, R., PONS, S. and MARTI, E. (2016). Delamination of neural crest cells requires transient and reversible Wnt inhibition mediated by Dact1/2. Development 143: 2194-2205.

RINON, A., MOLCHADSKY, A., NATHAN, E., YOVEL, G., ROTTER, V., SARIG, R. and TZAHOR, E. (2011). p53 coordinates cranial neural crest cell growth and epithelialmesenchymal transition/delamination processes. Development 138: 1827-1838.

ROGERS, C.D., JAYASENA, C.S., NIE, S. and BRONNER, M.E. (2012). Neural crest specification: tissues, signals, and transcription factors. Wiley Interdiscip Rev Dev Biol 1: 52-68.

ROYBAL, P.G., WU, N.L., SUN, J., TING, M.C., SCHAFER, C.A. and MAXSON, R.E. (2010). Inactivation of Msx1 and Msx2 in neural crest reveals an unexpected role in suppressing heterotopic bone formation in the head. Dev Biol 343: 28-39.

RUEST, L.B., DAGER, M., YANAGISAWA, H., CHARITE, J., HAMMER, R.E., OLSON, E.N., YANAGISAWA, M. and CLOUTHIER, D.E. (2003). dHAND-Cre transgenic mice reveal specific potential functions of dHAND during craniofacial development. Dev Biol 257: 263-277.

SENARATH-YAPA, K., LI, S., MEYER, N.P., LONGAKER, M.T. and QUARTO, N. (2013). Integration of multiple signaling pathways determines differences in the osteogenic potential and tissue regeneration of neural crest-derived and mesoderm-derived calvarial bones. Int J Mol Sci 14: 5978-5997.

SHAO, R., LIU, J., YAN, G., ZHANG, J., HAN, Y., GUO, J., XU, Z., YUAN, Z., LIU, J., MALUMBRES, M. et al., (2016). Cdh1 regulates craniofacial development via APC-dependent ubiquitination and activation of Goosecoid. Cell Res26: 699-712.

SIMOES-COSTA, M., TAN-CABUGAO, J., ANTOSHECHKIN, I., SAUKA-SPENGLER, T. and BRONNER, M.E. (2014). Transcriptome analysis reveals novel players in the cranial neural crest gene regulatory network. Genome Res 24: 281-290.

SINGH, N., GUPTA, M., TRIVEDI, C.M., SINGH, M.K., LI, L. and EPSTEIN, J.A. (2013). Murine craniofacial development requires Hdac3-mediated repression of Msx gene expression. Dev Biol 377: 333-344.

STOTTMANN, R.W., CHOI, M., MISHINA, Y., MEYERS, E.N. and KLINGENSMITH, J. (2004). BMP receptor IA is required in mammalian neural crest cells for development of the cardiac outflow tract and ventricular myocardium. Development 131: 2205-2218.

STUHLMILLER, T.J. and GARCIA-CASTRO, M.I. (2012). Current perspectives of the signaling pathways directing neural crestinduction. Cell Mol Life Sci69:3715-3737.

TABLER, J.M., RICE, C.P., LIU, K.J. and WALLINGFORD, J.B. (2016). A novel ciliopathic skull defect arising from excess neural crest. Dev Biol 417: 4-10.

TANEYHILL, L.A., COLES, E.G. and BRONNER-FRASER, M. (2007). Snail2 directly represses cadherin6B during epithelial-to-mesenchymal transitions of the neural crest. Development 134: 1481-1490.

TAVELLA, S. and BOBOLA, N. (2010). Expressing Hoxa2 across the entire endo- chondral skeleton alters the shape of the skeletal template in a spatially restricted fashion. Differentiation 79: 194-202.

TIAN, H., FENG, J., LI, J., HO, T.V., YUAN, Y., LIU, Y., BRINDOPKE, F., FIGUEIREDO, J.C., MAGEE, W., 3RD, SANCHEZ-LARA, P.A. etal., (2017). Intraflagellar transport 88 (IFT88) is crucial for craniofacial development in mice and is a candidate gene for human cleft lip and palate. Hum Mol Genet.26:860-872

UEHARA, M., YASHIRO, K., MAMIYA, S., NISHINO, J., CHAMBON, P., DOLLE, P. and SAKAI, Y. (2007). CYP26A1 and CYP26C1 cooperatively regulate anteriorposterior patterning of the developing brain and the production of migratory cranial neural crest cells in the mouse. Dev Biol 302: 399-411.

VAN DE PUTTE, T., FRANCIS, A., NELLES, L., VAN GRUNSVEN, L.A. and HUYLEBROECK, D. (2007). Neural crest-specific removal of Zfhx1b in mouse leads to a wide range of neurocristopathies reminiscent of Mowat-Wilson syndrome. Hum Mol Genet 16: 1423-1436.

VAN GIJN, D.R., TUCKER, A.S. and COBOURNE, M.T. (2013). Craniofacial development: current concepts in the molecular basis of Treacher Collins syndrome. $\mathrm{Br}$ J Oral Maxillofac Surg 51: 384-388.

VAN TRIER, D.C., VOS, A.M., DRAAIJER, R.W., VAN DER BURGT, I., DRAAISMA, J.M. and CRUYSBERG, J.R. (2016). Ocular Manifestations of Noonan Syndrome: A Prospective Clinical and Genetic Study of 25 Patients. Ophthalmology 123: 2137-2146.

WADA, H., HOLLAND, P.W., SATO, S., YAMAMOTO, H. and SATOH, N. (1997). Neural tube is partially dorsalized by overexpression of HrPax-37: the ascidian homologue of Pax-3 and Pax-7. Dev Biol 187: 240-252.

WANG, J., XIAO, Y., HSU, C.W., MARTINEZ-TRAVERSO, I.M., ZHANG, M., BAI, Y., ISHII, M., MAXSON, R.E., OLSON, E.N., DICKINSON, M.E. et al., (2016). Yap and Taz play a crucial role in neural crest-derived craniofacial development. Development 143: 504-515.

WANG, Y.C., JUAN, H.C., WONG, Y.H., KUO, W.C., LU, Y.L., LIN, S.F., LU, C.J. and FANN, M.J. (2013). Protogenin prevents premature apoptosis of rostral cephalic neural crest cells by activating the alpha5beta1-integrin. Cell Death Dis 4: e651:1-13

WEI, K., CHEN, J., AKRAMI, K., GALBRAITH, G.C., LOPEZ, I.A. and CHEN, F. (2007). Neural crest cell deficiency of c-myc causes skull and hearing defects. Genesis 45: 382-90.

WHITEHEAD, M.T., CHOUDHRI, A.F. and SALIM, S. (2013). Magnetic resonance imaging findings in Axenfeld-Rieger syndrome. Clin Ophthalmol 7: 911-916.

WIEACKER, P. and WIELAND, I. (2005). Clinical and genetic aspects of craniofrontonasal syndrome: towards resolving a genetic paradox. Mol Genet Metab86: 110-116.

WISZNIAK, S., HARVEY, N. and SCHWARZ, Q. (2016). Cell autonomous roles of Nedd4 in craniofacial bone formation. Dev Biol 410: 98-107.

XU, Y., MALLADI, P., ZHOU, D. and LONGAKER, M.T. (2007). Molecular and cellular characterization of mouse calvarial osteoblasts derived from neural crest and paraxial mesoderm. Plast Reconstr Surg 120: 1783-1795.

YAMAUCHI, Y., ABE, K., MANTANI, A., HITOSHI, Y., SUZUKI, M., OSUZU, F., KURATANI, S. and YAMAMURA, K. (1999). A novel transgenic technique that allows specific marking of the neural crest cell lineage in mice. Dev Biol 212: 191-203.

YUMOTO, K., THOMAS, P.S., LANE, J., MATSUZAKI, K., INAGAKI, M., NINOMIYATSUJI, J., SCOTT, G.J., RAY, M.K., ISHII, M., MAXSON, R. et al., (2013). TGFbeta-activated kinase 1 (Tak1) mediates agonist-induced Smad activation and linker region phosphorylation in embryonic craniofacial neural crest-derived cells. J Biol Chem 288: 13467-13480.

ZHANG, H., TAKEDA, H., TSUJI, T., KAMIYA, N., RAJDERKAR, S., LOUIE, K., COLLIER, C., SCOTT, G., RAY, M., MOCHIDA, Y. et al., (2015). Generation of Evc2/ Limbin global and conditional KO mice and its roles during mineralized tissue formation. Genesis.53: 612-626. 


\section{Further Related Reading, published previously in the Int. J. Dev. Biol.}

Trunk neural crest cells: formation, migration and beyond

Guillermo A. Vega-lopez, Santiago Cerrizuela and Manuel J. Aybar

Int. J. Dev. Biol. (2017) 61: 5-15

https://doi.org/10.1387/ijdb.160408gv

Galectin-1 enhances the generation of neural crest cells

Tsutomu Motohashi, Masahiro Nishioka, Daisuke Kitagawa, Norito Kawamura, Natsuki Watanabe, Takanori Wakaoka, Toshihiko Kadoyaand Takahiro Kunisada

Int. J. Dev. Biol. (2017) 61: 407-413

https://doi.org/10.1387/ijdb.160380tm

A new role of the membrane-type matrix metalloproteinase 16 (MMP16/MT3-MMP) in neural crest cell migration Lee Roth, Rotem Kalev-Altman, Efrat Monsonego-Ornan and Dalit Sela-Donenfeld

Int. J. Dev. Biol. (2017) 61: 245-256

https://doi.org/10.1387/ijdb.160286ds

Cell fate decisions during neural crest ontogeny

Chaya Kalcheim and Deepak Kumar

Int. J. Dev. Biol. (2017) 61: 195-203

https://doi.org/10.1387/ijdb.160196ck

Bone morphogenetic protein 4 promotes craniofacial neural crest induction from human pluripotent stem cells

Sumiyo Mimura, Mika Suga, Kaori Okada, Masaki Kinehara, Hiroki Nikawa and Miho K. Furue Int. J. Dev. Biol. (2016) 60: 21-28

https://doi.org/10.1387/ijdb.160040mk

Matrigel supports neural, melanocytic and chondrogenic differentiation of trunk neural crest cells

Ana B. Ramos-Hryb, Meline C. Da-Costa, Andréa G. Trentin and Giordano W. Calloni Int. J. Dev. Biol. (2013) 57: 885-890

https://doi.org/10.1387/ijdb.130206gw

Transcriptional regulation by Pax 3 and TGFbeta2 signaling: a potential gene regulatory network in neural crest development

Hiromichi Nakazaki, Yueh-Wei Shen, Beth Yun, Anvesh Reddy,Varun Khanna, Barbara Mania-Farnell, Shunsuke Ichi, David G. Mclone, Tadanori Tomita and C. Shekhar K. Mayanil Int. J. Dev. Biol. (2009) 53: 69-79

https://doi.org/10.1387/ijdb.082682hn

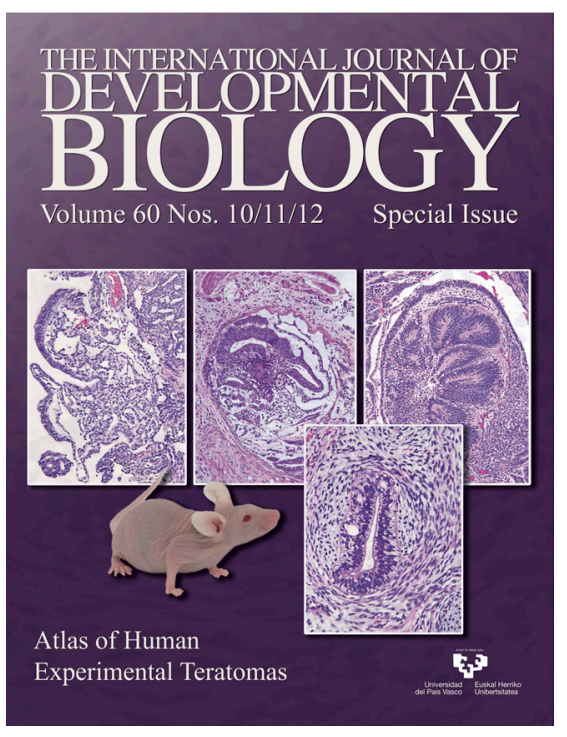

5 yr ISI Impact Factor $(2013)=2.879$

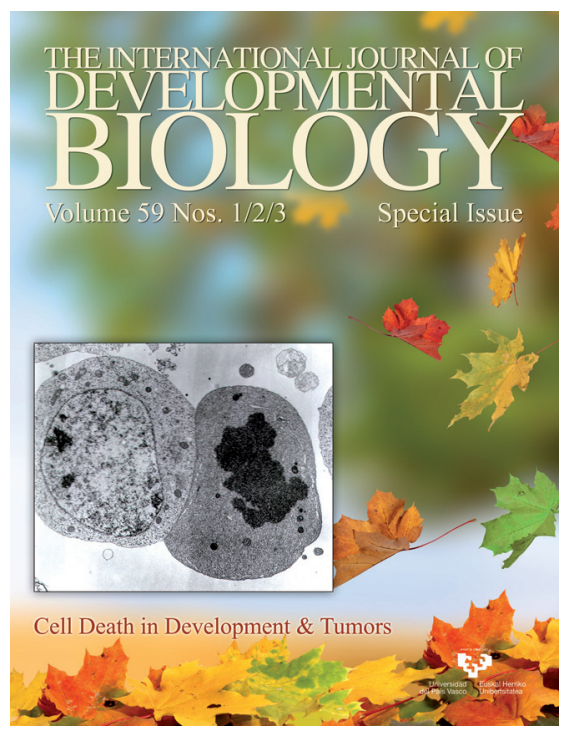

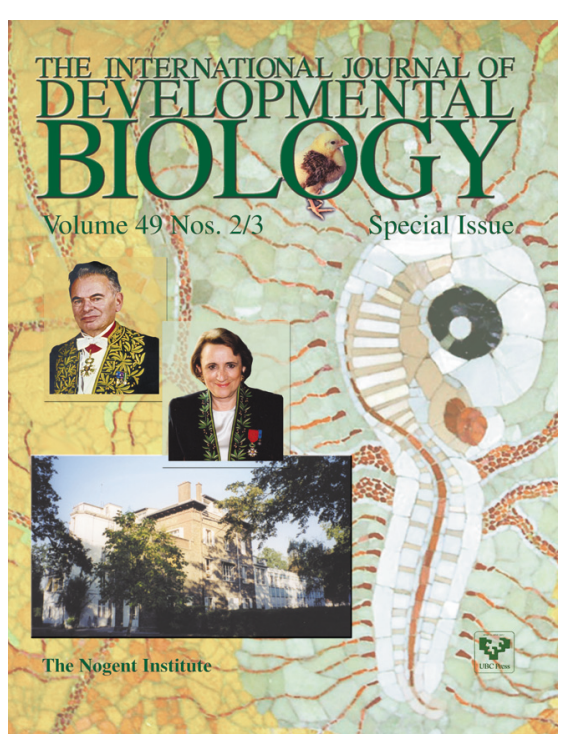

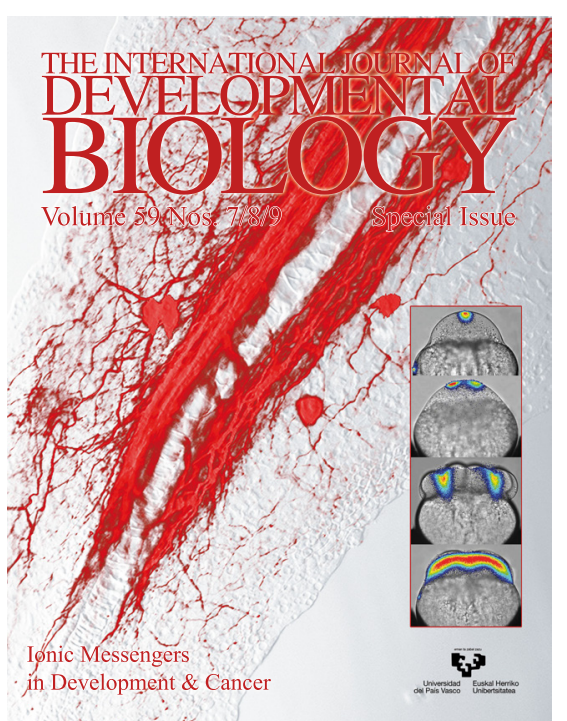

